Conferências 


\title{
ABERTURA XIII ENCONTRO NACIONAL DA ANPOLL
}

\author{
Eduardo Guimarães*
}

"A tolerância é filha da falta de fé. Crer é não distinguir".

Fernando Pessoa

omeço tomando por epígrafe um enunciado de Fernando Pessoa para me colocar mais perto de todos que constituem nossa

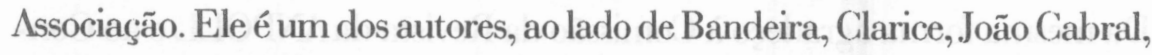
que tiveram papel decisivo na minha formação, na década de 60. Por isso, mais tarde, com prazer, tive a honra de ser dele editor.

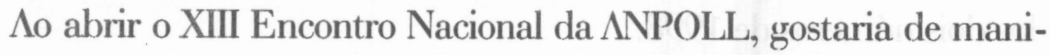
festar os agradecimentos da ANPOLL ao Instituto de Estudos da Linguagem da UNICAMP e à sua diretoria, tanto à gestão do Prof. Wanderlei Geraldi, que deu todo apoio institucional aos trabalhos de nossa $\Lambda$ ssociação, quanto à da Prof ${ }^{a}$. Raquel Salek Fiad, que não tem medido esforços para que este Encontro se dê da melhor maneira possível. Gostaria também de agradecer à $\Lambda$ dministração Superior da Universidade, tanto à Gestão do Prof. Martins, quanto à do Prof. Hermano Tavares, recentemente instalada. $\Lambda$ relação de respeito entre as universidades e as entidades científicas por elas abrigadas a cada período é o fundamento para que o trabalho destas associações possa ter a dimensão acadêmica e política que the é própria. Esta relação é o lugar que cria as condições para que estas $\Lambda$ ssociaçōes ajam com clara independência relativamente ao poder público. Agradeço, também, aos Coordenadores de Pós-graduação da área de Letras e Lingüística de todo o Brasil, por tudo que fizeram junto aos programas

* Professor da UNICAMP e ex-presidente da ANPOLL. 
GUTMARÄES, Eduardo. Abertura XIII Encontro Nacional da ANPOLL.

associados à $\Lambda$ NPOLL e que constituem nossa associação. Agradeço, ainda, aos Coordenadores dos Diversos Grupos de Trabalho, que dão o fundamento das atividades de pesquisa da $\Lambda$ NPOLL. Neste encontro, como a cada dois anos, foi com eles que constituímos esta intensa e importante programação do XIII Encontro Nacional. Nāo posso deixar de agradecer, também, a todos os funcionários da universidade que deram apoio às atividades da $\Lambda$ NPOLL, tanto os da Editora da UNICAMP, enquanto lá estive, quanto os funcionários do IEL por estes dois anos. Eles fazem parte indissociável da organização e andamento das atividades da $\Lambda$ NPOLL nesta gestão e para este Encontro.

Quero agradecer, ainda, o envolvimento de todos os membros da Diretoria e do Conselho da $\Lambda$ NPOLL, em todos os momentos necessários. Da mesma forma agradeço à Comissão da Revista da $\Lambda$ NPOLL e ao Conselho Editorial, que entenderam com entusiasmo nossa proposta de aumento da periodicidade de nossa Revista, que resulta, hoje, no lançamento dos dois números de 1998.

$\Lambda$ universidade brasileira passa por momentos difíceis. $\Lambda$ s universidades públicas federais e estaduais têm enfrentado problemas conjunturais e estruturais importantes. $\Lambda \Lambda$ NPOLL esteve empenhada, nestes últimos anos, junto com a SBPC e diversas outras associações científicas, na luta para que o orçamento da pesquisa no Brasil não fosse cortado. O resultado deste esforço, nem sempre é diretamente mensurável. Mas esperamos que ele seja parte das ações que, no decorrer da história, têm garantido o lugar da produção intelectual no Brasil. $\Lambda$ \NPOLL participou, também, de reuniões para a discussão da situação da pesquisa no Brasil hoje, e apoiou as universidades federais na sua luta por condições reais de trabalho, apoio que a $\Lambda$ NPOLL estende às universidades paulistas, neste momento de discussão de suas condições de trabalho e de salário.

$\mathrm{O}$ que as autoridades nảo compreendem, ou não querem compreender, ou esperam incompreender, é que negar condições reais de trabalho às universidades públicas neste momento é afetar, no médio e longo prazo, 
as condições de produção intelectual no Brasil. O que compremeterá a produção científica e tecnológica de todo tipo. E isto compromete o desenvolvimento do Estado brasileiro e sua sustentação, num momento em que os países com maior força econômica têm todas as vantagens do chamado processo de globallização. É preciso regionalizar a "globalização", se me permitem inserir esta contradição no próprio termo para fazê-lo deslizar para o interior de um discurso que nos interessa.

Nlém deste apoio conjuntural e decisivo às universidades públicas, cabe-nos posicionarmo-nos quanto à constituição das políticas públicas, de modo geral, e da política educacional e científica, em particular.

Não há futuro possível no mundo moderno que não inclua uma vida acadêmica forte e conseqüente. E o futuro é, para mim, o trabalho do presente sobre a memória. E é este trabalho do presente que precisamos saber constituir. $\mathrm{O}$ trabalho crítico do presente desautomatiza a memória e produz a diferença. E esta diferença, para nosso futuro, é o efeito do trabalho específico que agora realizamos. O trabalho crítico do presente nos faz atravessar as relações cristalizadas do passado para constituir um novo dizer e construir novas posições, novos percursos.

Se estamos na época em que as utopias são dadas como mortas, talvez devamos formular com parcimônia, precisão e força a utopia da real convivência do diferente e do desigual. Só esta convivência é capaz de garantir duas qualidades fundamentais da inteligência: a sutileza e a persistência. $\Lambda$ persistência de propósitos e a sutileza da descoberta e da reflexão. Deste modo, a vida intelectual não é uma forma de misticismo e religião e pode dar-se como afirmação e não como violência. Nesta medida uma política científica faz-se não a partir da afirmação do não da autoridade, mas do sim, cada vez diverso, dos pesquisadores. Este é o caminho para não se cair numa velada censura acadêmica nem na aceitação da falta de qualquer critério qualificado para o trabalho intelectual.

Segundo penso, esta busca de uma posição, nem cética, nem fundamentalista, é o espaço que temos que saber constituir neste momento da 
GUTMARÃES, Eduardo. Abertura XIII Encontro Nacional da ANP(OLL.

vida da universidade brasileira, para que a reflexão sobre o que é a universidade não seja meramente o reflexo de decisões dos governos e de alinhamentos entre administrações de universidades e as decisões de governos.

Isto é especificamente sensível para as áreas tidas como não técnicas, como é o caso do nosso campo de trabalho. Neste particular, assistimos na vida intelectual e cultural brasileira a uma tentativa de reduzir o principal, que são as condições humanas de vida, ao secundário, reduzilas ao adereço que embeleza, mas que desfigura e que pode, então, ser dispensado. O que acabo de formular é, para mim, uma descrição de um estado de coisas que tem merecido ações da Diretoria da ANPOLL no sentido de afirmar e colocar os aspectos relativos às artes, à literatura, à linguagem, no centro das procupações para se constituir o futuro. Este é um trabalho do presente para que o futuro não se reduza a uma dissimulação da história.

Não há sociedade que se desenvolva se dela se subtrair a linguagem e as artes. Sem isto não se tem o próprio do humano. Sem isto não há nenhum pensamento ou técnica possível. Ou seja, nós fazemos parte daqueles que têm como objetivo produzir e refletir sobre o que é o fundamento de qualquer sociedade e de qualquer futuro.

Segundo penso, este é o espírito que nos anima a todos, com matizes e com diferenças, para este XIII Encontro Nacional e para nossas ações tanto nas nossas pesquisas e no nosso trabalho de docência, como na nossa produção literária e artística.

$\Lambda$ Diretoria da $\Lambda$ NPOLL deseja a todos um Encontro frutífero e rico e que nosso trabalho insista para além de qualquer fronteira que queira se impor como limite ou restrição. Nós estamos aqui para um congrassamento da inteligência que sempre se faz com o olhar de quem sempre pergunta e questiona com simpatia e vontade. 